REINFORCED CONCRETE DESIGN BY COMPUTER 
Other Macmillan titles of related interest

Reinforced Concrete Design, Second Edition

W. H. Mosley and J. H. Bungey

Microcomputer Applications in Structural Engineering

W. H. Mosley and W. J. Spencer

Computer Spreadsheet Applications in Building and Surveying

B. Cooke and S. V. Balakrishnan

Practical BASIC Programming

P. E. Gosling

Program your Microcomputer in BASIC

P. E. Gosling

Civil Engineering Materials, Second Edition

N. Jackson (ed.)

Plastic Methods for Steel and Concrete Structures

Stuart S. J. Moy

Strength of Materials, Third Edition

G. H. Ryder

A Guide to the Preparation of Civil Engineering Drawings

M. V. Thomas

Structural Theory and Analysis, Second Edition

J. D. Todd

Energy Methods of Structural Analysis - Theory, worked examples and problems

B. A. Young 


\title{
REINFORCED CONCRETE DESIGN BY COMPUTER
}

\author{
R. Hulse \\ Department of Civil Engineering \\ Coventry (Lanchester) Polytechnic \\ and \\ Nanyang Technological Institute \\ Singapore \\ W. H. Mosley \\ School of Civil and Structural Engineering \\ Nanyang Technological Institute \\ Singapore
}

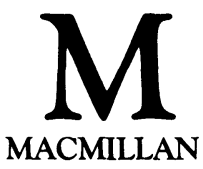


(C) R. Hulse and W. H. Mosley 1986

All rights reserved. No reproduction, copy or transmission of this publication may be made without written permission.

No paragraph of this publication may be reproduced, copied or transmitted save with written permission or in accordance with the provisions of the Copyright Act 1956 (as amended).

Any person who does any unauthorised act in relation to this publication may be liable to criminal prosecution and civil claims for damages.

First published 1986

Published by

MACMILLAN EDUCATION LTD

Houndmills, Basingstoke, Hampshire RG21 2XS

and London

Companies and representatives

throughout the world

British Library Cataloguing in Publication Data

Mosley, W. H.

Reinforced concrete design by computer.

1. Reinforced concrete construction-Data

processing

I. Title II. Hulse, R.

$624.1^{\prime} 8341^{\prime} 0285$ TA683.2

ISBN 978-0-333-44550-1 ISBN 978-1-349-18930-4 (eBook)

DOI 10.1007/978-1-349-18930-4

\section{Computer Program Disclaimer}

Neither the publisher nor the authors warrants the given programs to execute other than the displayed output of the given design examples and only then if the programs and data are correctly entered into a computer.

Any use of the programs to solve problems other than those given is the sole responsibility of the user as to whether the output is correct and is correctly interpreted and whether the use of the program is appropriate for the situation in which it is being used. 
To Jean and Wendy 


\section{Contents}

$\begin{array}{ll}\text { Preface } & \text { ix }\end{array}$

Notation xi

1. Introduction - Design and the Computer 1

1.1 The nature of design 1

1.2 The attributes of the computer 3

1.3 Computers and design 3

1.4 Computers - an aid or otherwise? 6

1.5 Developing a computer-aided design system 7

1.6 Reinforced concrete design by computer 14

2. Programs for the Analysis of the Structure 17

2.1 Limit state analysis of a single span beam 17

2.2 Continuous beam program 26

2.3 Envelope program 36

2.4 Substitute frame analysis $\quad 47$

2.5 Moment redistribution 49

2.6 Continuous beam with a varying cross-section 54

3. Beam Analysis and Design 68

3.1 Section analysis for bending resistance $\quad 69$

3.2 Design of bending reinforcement 79

3.3 Design of shear links 91

3.4 Design for torsion 96

4. Slab Design 104

4.1 One way spanning slabs 104

4.2 Two way spanning solid slab - simply supported without
torsional restraint

4.3 Two way spanning solid slab with torsional restraint 106

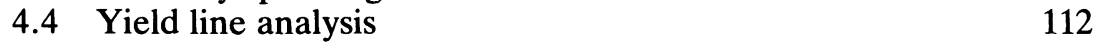

4.5 Shear design of solid slabs 118

$\begin{array}{ll}4.6 \text { Punching shear } & 119\end{array}$ 
5. Column Design 127

$\begin{array}{lll}5.1 & \text { Rectangular section column analysis } & 129\end{array}$

5.2 Rectangular section column design - symmetrical arrangement of reinforcement

5.3 Rectangular section column design - unsymmetrical

5.4 Rectangular section column $-N / M$ interaction curves 148

5.5 Non-rectangular section column $-N / M$ interaction curves 154

5.6 Biaxial bending of short rectangular columns symmetrical arrangement of reinforcement 162

$\begin{array}{lll}5.7 & \text { Effective height calculations } & 169\end{array}$

$\begin{array}{ll}5.8 \text { Slender columns } & 175\end{array}$

6. Foundation Design 186

6.1 Pad footing sizing and design 186

$\begin{array}{ll}6.2 \text { Beam on elastic support } & 199\end{array}$

$\begin{array}{ll}6.3 \text { Combined footing sizing } & 210\end{array}$

7. Serviceability and Detailing 217

$\begin{array}{lll}7.1 & \text { Span-effective depth calculations } & 217\end{array}$

$\begin{array}{lll}7.2 & \text { Deflection calculations } & 224\end{array}$

$\begin{array}{lll}7.3 & \text { Crack width calculations } & 234\end{array}$

$\begin{array}{lll}7.4 & \text { Ties } & 241\end{array}$

$\begin{array}{lll}7.5 & \text { Bar bending schedules } & 247\end{array}$

8. Program Enhancements, Files and Graphics 255

$\begin{array}{lll}\text { 8.1 Program enhancements } & 255\end{array}$

8.2 Use of files for program and data storage 263

$\begin{array}{ll}8.3 & \text { Using computer graphics } \\ & 272\end{array}$

Appendix: Glossary of BASIC Statements 283

$\begin{array}{ll}\text { Bibliography } & 285\end{array}$

$\begin{array}{lr}\text { Index } & 287\end{array}$ 


\section{Preface}

The aim of this text is to demonstrate how the principles and methods of limit state reinforced concrete design can be incorporated into simple, easy-to-use computer programs and provide an understanding of the role of small computers in the design and detailing of reinforced concrete structures.

At the present time many practising engineers and students of Civil/Structural Engineering have some familiarity with the application of the powerful yet inexpensive computers that are now available. Further developments in computer aided design techniques will ensure that there will be a growing interest in this area so that it will become an essential subject to be studied and understood by most Structural Engineers.

This book will assist in the understanding of the fundamental concepts of combining reinforced concrete design methods with computing techniques. It will enable an engineer to create and implement his own suite of programs in order to carry out routine design calculations or to more easily perform the more complex design requirements of modern limit state design methods. It will also aid the student engineer's understanding of the logical application of the limit state approach to reinforced concrete design.

Each chapter in the book presents a series of programs, written in the BASIC language, covering the more important and/or numerically orientated aspects of reinforced concrete design. The techniques involved are explained with written text, flow charts and examples. Throughout the book emphasis is placed wherever possible on developing programs from the fundamental principles of structural behaviour, and these principles are presented, together with the requirements of the British Standard, BS 8110, at the beginning of each section.

The programs given are intended to be a source of study and further development by the reader. They should not be seen as complete and comprehensive design programs but rather as the foundations of a design system which can be developed further. Suggestions for possible further development are given at the end of some of the program sections and these can be treated as programming/design exercises which, together with the introduction of some of the features discussed in the final chapter, can lead to the development of a comprehensive suite of design programs. The programs have been written in simple BASIC, so that they can be readily understood by the reader who is 
familiar with the BASIC language and can be implemented on any computer with only the minor changes necessary to suit the variations to be found on different machines. A list of the BASIC statements used can be found in the appendix. A bibliography is also provided for the benefit of the reader who wishes to pursue in more detail the theoretical background to limit state design methods.

The first chapter discusses the role of the computer in design. Chapter 2 gives programs for the analysis of the continuous beam and substitute frame. Chapters 3-6 are concerned with the design of beams, slabs, columns and foundations at the ultimate limit state while chapter 7 covers serviceability requirements. The final chapter discusses techniques for incorporating features which will enhance the use and presentation of the programs, combining the programs into a design suite using computer file systems and the use of computer graphics.

Finally the authors would like to thank Miss Jamillah Sa'adon who typed most of the manuscript and Miss Suzie Ding for helping with the program listings. Also our thanks to Professor Chen Charng Ning, Dean of the School of Civil and Structural Engineering at Nanyang Technological Institute, Singapore, for his encouragement during the time that the authors worked at NTI. 


\section{Notation}

The notation used throughout the book is in accordance with BS 8110, and symbols used are defined in the text. In the programs a set of variable names has been adopted which generally reflects this notation. For example, all stresses have variable names commencing with the letter ' $F$ ' to reflect the use of the lower case ' $\mathrm{f}$ '.

As many variables, such as the characteristic strength of concrete, are common to a number of programs, a set of variable names has been 'reserved' to have the meanings given in the list below. Other variable names unique to a particular program are given in the description of that program. For the sake of conciseness, variables used only as, for example, loop counters are not given in the description.

\section{'Reserved' variable BS 8110} name

\begin{tabular}{|c|c|c|}
\hline A & $A_{\mathrm{c}}$ & Area of concrete \\
\hline $\mathrm{AC}$ & $A_{\mathrm{s}}^{\prime}$ & Area of compression reinforcement \\
\hline AS & $A_{\mathrm{s}}$ & Area of tension reinforcement \\
\hline AV & - & $A_{\text {sv }} / s_{\mathrm{v}}$ ratio for shear links \\
\hline B & $b$ & Breadth of section \\
\hline BF & - & Breadth of flange \\
\hline BW & $b_{\mathbf{w}}$ & Breadth of web \\
\hline $\mathrm{CM}$ & - & Minimum cover to reinforcement \\
\hline D & $d$ & $\begin{array}{l}\text { Effective depth of tension } \\
\text { reinforcement }\end{array}$ \\
\hline D1 & $d^{\prime}$ & Depth to compression reinforcement \\
\hline DI & $\varphi$ & Bar diameter \\
\hline $\mathrm{E}$ & $\epsilon$ & Strain \\
\hline $\mathrm{EC}$ & $E_{\mathrm{c}}$ & Young's modulus of concrete \\
\hline ES & $E_{\mathrm{s}}$ & Modulus of elasticity steel \\
\hline FU & $f_{\mathrm{cu}}$ & Characteristic concrete cube strength \\
\hline FV & $f_{\mathrm{yv}}$ & $\begin{array}{l}\text { Characteristic strength of link } \\
\text { reinforcement }\end{array}$ \\
\hline FY & $f_{\mathrm{y}}$ & Characteristic strength of reinforcemen \\
\hline
\end{tabular}




\begin{tabular}{|c|c|c|}
\hline GK & $G_{\mathbf{k}}$ & Characteristic dead load \\
\hline $\mathrm{H}$ & $h$ & Overall depth of section \\
\hline HF & $h_{\mathrm{f}}$ & Thickness of flange \\
\hline I2 & $I$ & Second moment of area \\
\hline $\mathbf{L}$ & $l$ & Length \\
\hline $\mathbf{M}$ & $M$ & Bending moment \\
\hline MR & $\alpha_{e}$ & Modular ratio \\
\hline MU & $M$ & Ultimate moment of resistance \\
\hline $\mathbf{N}$ & $N$ & Axial load at section \\
\hline QK & $Q_{\mathrm{k}}$ & Characteristic imposed load \\
\hline RO & $\rho$ & $=100 A_{\mathrm{s}} / b d$ \\
\hline SV & $s_{\mathbf{v}}$ & Spacing of links along a member \\
\hline $\mathbf{T}$ & $T$ & Torsional moment due to ultimate loads \\
\hline $\mathrm{T} \$$ & - & $\begin{array}{l}\text { Title used as first item of input data to } \\
\text { each program }\end{array}$ \\
\hline $\mathbf{X}$ & $x$ & Neutral axis depth \\
\hline
\end{tabular}

